\title{
Strategy to Develop the Ability of Creative Thinking Using Problem-Based Learning Model in Light Vehicle Engineering Competences of Vocational Education
}

\author{
Suparji ${ }^{1}$, Luthfiyah Nurlaela ${ }^{2}$, Bima Anggana Widhiarta Putra ${ }^{3}$ \\ Building Engineering Education Department ${ }^{1}$ \\ Home Economic Department ${ }^{2}$ \\ Technology and Vocational Education ${ }^{3}$ \\ State University of Surabaya \\ Surabaya, Indonesia \\ suparji@unesa.ac.id
}

\begin{abstract}
The results of several studies revealed that the level of creative thinking ability of middle school students is still low, including ones of vocational high schools. Therefore, learning strategies that can improve the ability of high-level thinking, one of which is the ability of creative thinking, is required. This study aimed to develop problem-based learning tools to improve the creative thinking skills of vocational school students. In addition, it was to describe the process of applying problem-based learning model to improve students' creative thinking ability. The research instrument used was learning tool including syllabus, lesson plan, student activity sheet, and test result of creative thinking. Data collection employed test, observation, and questionnaire. Data analysis used descriptive analysis and test to differentiate learning outcomes before and after problem based learning process. The results showed that the tool of problem-based learning model could improve students' creative thinking ability indicated by the difference in learning outcomes before and after the learning process based on the problem is significant. In addition to these results, it also proved that the implementation of problem-based learning was very effective and the students' responses to learning with the model were good.
\end{abstract}

Keywords - teaching and learning process, creative thinking skills, vocational high schools

\section{INTRODUCTION}

One of the international studies on cognitive abilities is the Trend in Mathematics and Science Study (TIMMS) conducted by the International Association for the Evolution of Educational Achievement (IEA), which found that in 2007 and 2011, more than $95 \%$ of Indonesian students were only able to achieve middle-level thinking skills, while in Taiwan nearly $50 \%$ of the learners were able to achieve the ability to think ahead and in an advance level. This happened because in the learning process at school, students were generally less stimulated to improve high-order thinking skills. In addition to that many educators are lacking in using learning that demands high-order thinking [1]. Therefore, it takes transformation in terms of education, from learning by memorizing to learning to think, or studying the superficial to be profound or complex.
High-level thinking is defined as the wider use of the mind to discover new challenges. According to Wagner entering an era of increasingly strong competition, high-level thinking ability becomes the key to success. Now more and more schools in the developed world are providing graduates with the ability to "be critical thinkers, be problem solver, and be creative" [2]. In line with this according to Trilling \& Fadel states there are three abilities that must be grown school; the three capabilities are creativity and innovation, critical thinking and problem solving and communication and collaboration [3]. Based on this, a learning strategy to increase the ability of high-level thinking is required, i.e. strategies to improve the ability of high-level thinking. In this case is devoted to improve the ability of creative thinking. The ability to think creatively is considered important because studies conducted by the World Bank show that the benefits of a country $45 \%$ determined by innovation. Meanwhile, according to Trilling and Fadel innovation is nothing but the product of creativity. The ability to think creatively is necessary for the competence of Indonesian human resources that is not inferior to other nations [4]

High-level thinking is a mind-set ability to generate new ideas. Creativity is the ability to develop new ideas and to discover new ways of looking at problems and opportunities. The ability to think creatively is a mental activity to make connections (continuous), so that, to find the right combination [5]. While Craft mentions that creativity is a new way of implementing knowledge and skills [6]. Creative thinking is thinking consistently and continuously producing something creative or original in accordance with the needs [7]. Slightly different from the above view Boyd explained In addition to out of the box, to be creative can also be done by thinking in side the box [8]. So from some opinions above can be concluded that creativity is the ability to think to produce something new, but it can also improve the existing patterns of thinking to solve a problem.

According to Suparji, creativity is a process of thinking that can be improved, where the creativity of a person must be known first creativity owned and then can be planned how to develop the creativity [9]. Creative thinking is a thinking 
process that has characteristics of fluency, flexibility, and originality. Smoothness is the ability to come up with the correct idea or idea as much as possible clearly. Flexibility is the ability to expend many diverse ideas and ideas that are not monotonous by looking from different angles. Originality is the ability to generate unique or unusual ideas or ideas, for example different from those in books or different from others' opinions. Elaboration is the ability to explain the factors that influence and add to the detail of the idea so that it is more valuable [10]. Components in creative thinking is the problem of sensivity that is the ability to recognize a problem or ignore the fact that is less appropriate (misleading fact), and originality is the ability to build ideas in general [11].

Vocational High School (popularly known as Sekolah Menengah Kejuruan or SMK) is mandated by the law to prepare human resources ready to enter the workforce and become a productive workforce. SMK graduates ideally are ready-made workers, can work directly in the business or industry. The human resources in question must be in accordance with the predefined graduate competency standards with the criteria of graduate qualification that includes attitude, knowledge, and skills. In addition SMK also has the obligation to equip learners with logical, analytical, systematic, critical, and creative thinking skills, which requires students to participate actively participate (student-centered). With active learning learning students increasingly understand through learning by doing. Active learning helps students to develop knowledge flexibly, effective problem solving skills, selfdirected learning, effective collaborative skills and intrictive motivation [12]. Active learning also emphasizes learning through problem solving [13].

Innovative learning is a more student centered learning. That is, more learning provides opportunities for students to construct knowledge independently (self directed). Given the main purpose of learning to develop creative thinking skills, the learning model should be designed to encourage students to analyze some critical things and then encourage students to generate ideas. Various innovative learning models include problem-based, project-based, collaborative, cooperative learning models, with various approaches used, such as scientific and contextual approaches. It is also possible to apply various learning strategies.

Related to this, to develop creative thinking ability teachers no longer use conventional learning model, i.e. teacher centered learning. Students are given more opportunities to develop their own skills (student centered). Critical and creative thinking is used in problem solving. To think creatively, one needs critical thinking skills in analyzing problems creatively. Conversely, to master critical thinking, especially in solving problems it requires creativity, to find a good solution [14]. Based on this model of learning that is considered capable of improving the ability of creative thinking is a problem-based learning model.

Problem-based learning is a method of teaching by means of learners faced with a problem that must be solved based on accurate data or information to obtain a conclusion [15]. Along with that Arends explains problem based learning is a learning approach where learners work on authentic issues with the intent to compile their own knowledge [16]. Problem-based learning is one of the learning approaches used to stimulate high-level thinking of students in real-world-oriented situations, including how to learn. Problem-based learning is recognized to enhance the ability of creative thinking, referring to Semiawan's statement that the application of problem-based learning can improve the creativity especially aspects of flexibility and fluency [17].

Problem-based learning model in addition to having a theoretical base as the basis for its development, implementation goals, management of learning, also has a syntax or steps in the process of implementation of learning. The syntax of problem-based learning includes five steps that must be applied in the learning process, among others; (1) student orientation in problem; (2) organizing students to learn; (3) guiding in the investigation; (4) developing and presenting the work; and (5) analyzing and evaluating the problemsolving process. Research in terms of developing problembased learning tools is done to improve the ability of creative thinking of vocational high school students. This study was conducted with the aim to analyze whether the application of problem learning model can improve the ability of students' creative thinking and teacher's implementation in applying problem-based learning model. Another purpose of the research is to describe the success of the problem-based learning model to improve the ability to think creatively and analyze the students' responses to the learning components developed

\section{METHOD}

This study aimed to develop problem-based learning tools to improve the creative thinking skills of vocational students, as well as apply them. The research instruments included the Learning Results Test (popularly known as THB) of creative thinking that embraces the HOT'S making feature of linking different information, the Lesson Plans (popularly known as RPP), syllabus, Student Activity Sheet (popularly known as LKS), the instrument of lesson plan implementation, student activity instruments, and student response questionnaires. This research was conducted at SMK Special Navy 1 Surabaya, in Expertise Competences of Light Vehicle Engineering (popularly known as TKR) on automotive basic job learning material. The subjects of this study were 33 students of TKR Class X. Data collection techniques were observation, tests, questionnaires, and documentation. Data analysis techniques were descriptive and inferential statistics. Descriptive statistics are used to explain the results of lesson plan implementation and student responses. While the inferential statistic uses paired t test to compare the test result of creative thinking ability before (pre-test) and after learning (post-test) and compare ability of creative thinking at every meeting

\section{RESUlT AND DisCUSSION}

The results of this study are devided into four groups, namely the results of learning results data, the ability to think creatively, the implementation of learning, and student responses. 
A. Creative Thinking Ability

TABLE I. Results of T-PAired TEST OF CREATIVE THINKING

\begin{tabular}{|c|c|c|c|c|c|c|}
\hline \multicolumn{7}{|c|}{ Paired Samples Test } \\
\hline & & & \multicolumn{2}{|c|}{ Paired Differences } & \multirow[b]{2}{*}{$D f$} & \multirow[b]{2}{*}{$\begin{array}{l}\text { Sig. (2- } \\
\text { tailed) }\end{array}$} \\
\hline & & & Mean & $\begin{array}{c}\text { Std. } \\
\text { Deviation }\end{array}$ & & \\
\hline Pair 1 & $\begin{array}{l}\text { Postest } \\
\text { Creative } \\
\text { Thinking } \\
\text { Ability } \\
\text { Prestest }\end{array}$ & - & 4.82 & 1.14 & 32 & .000 \\
\hline
\end{tabular}

The ability to think creatively before learning (pre-test) and after learning (post-test) showed significant results. The result was proved by using t-paired test. Based on the result of tpaired test, the probability value (sig. 2-tailed) was obtained 0.000 . This value was smaller than the significant level of $5 \%$ (sig 0.05), it can thus be concluded that there is a difference of creative thinking ability obtained by students of SMK Special of Navy 1 Surabaya before and after learning activity based on problem-based learning.

Problem-based learning model is a learning approach with practical problems, shaped open ended through stimulus in learning [18]. Relevant to that according to Cannon problembased learning model is an innovative learning model and can provide active learning conditions to learners, so that students can learn the knowledge related to the problem as well as have the skills to solve problems [19]. In addition PBM serves to stimulate high-level thinking students in solving a problem.

\section{B. Improving Creative Thinking Ability}

TABLE II. RESULTS OF DIFFERENCE TESTING OF CREATIVE THINKING

\begin{tabular}{|c|c|c|c|c|c|}
\hline \multicolumn{6}{|c|}{ Paired Samples Statistics } \\
\hline & & Mean & $N$ & $\begin{array}{c}\text { Std. } \\
\text { Deviation }\end{array}$ & $\begin{array}{c}\text { Std. Error } \\
\text { Mean }\end{array}$ \\
\hline \multirow{2}{*}{ Pair 1} & $\begin{array}{l}\text { Creative Thinking } \\
\text { Ability } \\
\text { Meeting } 2\end{array}$ & 8.80 & 33 & .79 & .13 \\
\hline & $\begin{array}{l}\text { Creative Thinking } \\
\text { Ability } \\
\text { Meeting } 1 \\
\end{array}$ & 7.94 & 33 & 1.50 & .26 \\
\hline
\end{tabular}

Technique of data analysis was to know improvement of test result of learning ability of student creative thinking at every meeting using quantitative descriptive test and inferential statistics that is t-paired test. Analysis of the data aimed to compare the ability to think creatively at meetings 1 and 2 with learning activities using problem based learning. The average score obtained at the first meeting was 7.94 while the second meeting was 8.80 . If the two numbers were compared then obviously there was an increase (delta) of 0.86 , meaning that there is an increase in creative ability of 0.86 students.
TABLE III. RESULTS OF T-PAIRED TESTS OF CREATIVE THINKING ABILITY AT EVERY MEETING

\begin{tabular}{|c|l|c|c|c|c|}
\hline \multicolumn{5}{|c|}{ Paired Samples Test } \\
\cline { 2 - 3 } & \multicolumn{2}{|c|}{ Paired Differences } & \multirow{2}{*}{ Mean } & $\begin{array}{c}\text { Std. } \\
\text { Deviation }\end{array}$ & $\begin{array}{c}\text { Sig. (2- } \\
\text { tailed) }\end{array}$ \\
\hline Pair 1 & $\begin{array}{l}\text { Creative } \\
\text { Thinking ability } \\
\text { Meeting 2- } \\
\text { Creative } \\
\text { Thinking ability } \\
\text { Meeting 1 }\end{array}$ & .86 & 1.44 & 32 & .002 \\
\hline
\end{tabular}

If done with t-paired test, the result of the probability value (sig. 2-tailed) was 0.002 and this figure is smaller than $5 \%$ significant level (sig .0.05), so it can be concluded that there is a significant difference between creative thinking obtained by students of SMK Negeri 1 Surabaya Special Class at meeting 1 and meeting 2 using problem based-learning activity base learning. The difference tends to increase the score from the first meeting of 7.94 and the second meeting of 8.80 .

According to Djamarah and Zain, the essence of learning is repetition. This can mean that to achieve learning achievement, then a student must be diligent to repeat the lesson [20]. In other words, a learner who wants to achieve good learning outcomes must form a pattern (habit) so that learning behavior is efficient. In this case Slameto states that learning habits will affect learning outcomes [21]. Relevant to that according to Bandura there are four important elements in learning. The four important elements are attention, retention, reproduction, and motivation. In the reproduction points explains that repetitive exercise done by students makes learning and performance results more fluent and more adept [22]. Similarly, the ability to think creatively, in this research proves that there is an increase in creative thinking ability to students if there is a habituation. Habituation in this case is in problem solving and test of learning outcomes that build creative thinking ability as well as learning models that give freedom to explore their knowledge.

Observation of the lesson plan implementation was conducted by two observers. The observation activity was done by using the observation sheet of the implementation of lesson plan. Observed aspects included preliminary activities, core activities, and closing activities, in accordance with the syntax of problem-based learning. The results obtained that the assessment of two observers on the implementation of problem-based lesson plan at the first and second meeting had an average value of 3.84. This value indicated that the teacher performed the lesson plan in accordance with the syntax of the problem-based learning model well. This is very possible, because before implementing the lesson, the teacher simulated first. The success of a learning activity was determined by the lesson plan, because in the lasson containsed the steps or scenarios that were done by teachers and students in the learning process.

Questionnaire of student responses to learning activities was given to students after learning. The students' responses were intended to obtain students' responses from material aspects/ content of the lesson, learning media, THB, LKS format, learning atmosphere, and teacher teaching. The student 
response data showed that the novelty of learning material as much as $63.64 \%$ of the students stated new, as much as $34.85 \%$ stated quite new, and equal to $1.51 \%$ student stated not new. Judging from the easiness aspect in understanding learning, $56.36 \%$ of of the students considered it easy; $37.89 \%$ of the students stated quite easily; and $5.75 \%$ of the students responded it was not easy. Based on the aspect of interest in learning, $72.73 \%$ of the students were interested in learning and $36.37 \%$ of the students were fairly interested and $0.76 \%$ of the students expressed no interest. Judging from the way teachers taught in learning, as many as $60.61 \%$ of the students felt clear and $36.40 \%$ of the students felt quite clear.

From the data above the learning process will run smoothly when accompanied by interest. Therefore, teachers need to generate student interest so that the lessons given are easy for students to understand [23]. In the problem-based learning model in the presentation of the learning process encourages students to seek and solve a problem in order to achieve learning [24]. In parallel with this method of problem-solving provides opportunities for learners to play an active role in studying, searching and finding their own information to be processed into concepts, principles, theories and conclusions [25]

\section{CONCLUSION}

Based on the data of the research results, some conclusions can be drawn, they are: 1) there are significant differences between the results of creative thinking learning obtained by students before and after problem based learning, 2) there is significant improvement between the test results of creative thinking in every meeting, 3) The lesson plan achieves criteria that are well-executed, appropriate, systematic, and timely, and 4) the students' response to this project-based learning activity is good, which places the highest aspect in the interest.

\section{ACKNOWLEDGEMENT}

This research was supported by University State of Surabaya. We thank our colleagues from engineering faculty and previous researchers who provided insight and expertise that greatly assisted the research, although they may not agree with all of the conclusions of this paper.

\section{REFERENCES}

[1] Samani, M and Suparji, "Teaching-learning strategy for developing critical thinking and creativity for engineering student teachers". Paper presented on TVET International Conference at Bremen UniversityGermany, September 2-4, 2015.

[2] Wagner, Tony, "The global achievement gap: why even best schools don't teach the new survival skills our children need-and what we can do about it, $1^{\text {st }}$ ed. New York: Basic Books Group, 2008, pp. 14-34

[3] Trilling, Bernie \& Charles Fadel, $21^{\text {st }}$ Centuty skills: learning for life in our times, $1^{\text {st }}$ ed. San Fransisco: Jossey-Bass, 2009, pp. 49

[4] Trilling, Bernie \& Charles Fadel, $21^{\text {st }}$ Centuty skills: learning for life in our times, $1^{\text {st }}$ ed. San Fransisco: Jossey-Bass, 2009, pp. 56

[5] Evans, J.R, "Creative thinking in the decision and management sceinces, $1^{\text {st }}$ ed. Ohio: South-Western Publishing Co, 1991, pp. 15

[6] Craft, A, Jeffrey, B, Creativity in education: current perspective on policy and practice, $1^{\text {st }}$ ed. London: Cassel Ltd, 2001, pp.68-73.
[7] Nurlaela, L. \& Euis I, Strategi belajar berpikir kreatif, $1^{\text {st }}$ ed. Yogyakarta: Ombak, 2015, pp. 10

[8] Boyd, Drew \& Jacob Goldenberg, Inside the box: why the best business innovation are in front of you, London: Profile Book Ltd, 2013.

[9] Suparji, "Creative thinking level of student in measuring situation map area thourgh multiple solution tasks (case study on nganjuk state-1 vocational high school)”. J. Basic. Appl. Sci. Res., 7(7) 28-33, 2017.

[10] Filsaime, D. K, Menguak rahasia berpikir kritis dan kreatif. Jakarta: Prestasi Pustaka. 2008, pp. 21.

[11] Evans, J.R, "Creative thinking in the decision and management sceinces, $1^{\text {st }}$ ed. Ohio: South-Western Publishing Co, 1991, pp. 47.

[12] Belland, Brian R., French, Brian F. French \& Peggy A. Ertmer, "Validity and problem-based learning research: a review of instruments used to assess intended learning outcomes," Interdisciplinary Journal of Problem-based Learning: Vol. 3: Iss. 1, Article 5. Available at: http://docs.lib.purdue.edu/ijpbl/vol3/iss1/5, 2009.

[13] Emily, Hunt, Pamela Lockwood-Cooke, Judy Kelley, "Linked-class problem-based learning in engineering: method and evaluation", American Journal of Education Engineering volume 1 number 1, 2010.

[14] Samani, M. \& Luthfiyah Nurlaela, Berpikir tingkat tinggi problem solving. Surabaya: Sarbikita Publishing, 2016, pp. 20.

[15] Nurlaela, L, Developing creative thinking skills in learning at highereducational institution of teacher. Advances in Social Science, Education and Humanities Research. March, 2015. p: 114-119. www.atlantis - press.com

[16] Arends, Richards I, Classroom instructional and management. New York: The McGrw-Hill Companies, 1997, p.45.

[17] Semiawan, C. R, "Kreativitas keberbakatan: mengapa, apa, bagaimana. Jakarta: PT Indeks. 2010, pp. 50.

[18] Fogarty, R, Problem based learning ang multple intelligences classroom. Melbourne: Hawker Brownlow Education,1997.

[19] Cannon, K.C, Synthesis of complec natural product as vehicle for student-centered, problem base learning. journal of chemical education, 75(10), 1259-1260. august 1998.

[20] Djamarah, Syaiful Bahri dan Aswan Zain, Strategi belajar mengajar. Jakarta: Rineka Cipta: Jakarta, 2006, p.57.

[21] Slameto, Belajar dan faktor-faktor yang mempengaruhinya. Jakarta: Rineka Cipta, 2003, pp. 67.

[22] Nur, M, Pendekatan-pendekatan konstruktivis dalam pembelajaran. Surabaya: IKIP Surabaya, 1998, pp.55.

[23] Hasnawiyah, Minat dan motivasi siswa terhadap jurusan biologi pada sma. Ujungpandang: IKIP Ujungpandang, 1994.

[24] Nurlaela, L. \& IGP Asto Buditjahjanto, Implementasi teknologi informasi dan komunikasi dalam pembelajaran bidang vokasi. Jurnal Teknologi Pendidikan, Teori dan Praktik. 2013.

[25] Hamalik, O, Psikologi belajar dan mengajar. Bandung: Sinar Baru Algensindo, 1999. 